\title{
More Unstable Internally, More Reliable Externally: South Korea's Participation in the Vietnam War
}

\author{
Sung Chul Jung
}

\begin{abstract}
Which states are reliable alliance partners? Previous realist and institutional studies highlight two factors, common threat and joint democracy, respectively. This study focuses our attention on political unrest as a factor affecting alliance commitment. In particular, it hypothesizes that domestically-troubled states are more likely to join wars for their stronger allies because the leaders expect both rally-round-the-flag effects as well as military and economic benefits from the senior partners. A plausibility probe study of South Korea's participation in the Vietnam War provides some support for the diversionary approach that domestically-troubled states are reliable alliance partners. Park Chung Hee expressed his preference to send troops to Southeast Asia just after his successful military coup in 1961 and responded actively to the U.S. call for "more flags" in 1964. By showing his anti-communist stance and commitment to alliance with the Unite States, he hoped to maintain, if not increase, U.S. support, military and economic, that was essential not only for South Korea's security and development but for his political survival and control of domestic politics. Actually, he could prove himself to disgruntled domestic audience as one providing "guns" and "butter" with U.S. support in return for his sending troops to Southeast Asia.
\end{abstract}

Key Words: alliance, diversionary incentive, domestic unrest, South Korea, the Vietnam War

$\mathrm{S}$ tates sometimes fight for their friends. For example, the United States joined the Korean War for South Korea, sent troops to Southeast Asia for South Vietnam, and saved Kuwait from Iraq's attack. Why and when do states join war for their alliance partners? Many international relations scholars often highlight common threat in order to explain alliance formation. According to this view, common enemies create friendship. However, not all states help friends-in-need. According to Leeds, Long, and Mitchell (2000), states honor their alliance treaties by joining wars for their alliance partners in $74.5 \%$ of the time. Why do states sometimes help their alliance partner and sometimes not do so? What

*Sung Chul Jung(sungchul.jung@gmail.com) is Assistant Professor in the Department of Political Science and Diplomacy at Myongji University. He teaches and researches international relations, foreign policy analysis and East Asian politics. He has published his research in academic journals such as International Studies Quarterly and Journal of Peace Research. 
account for states' alliance commitment?

This study focuses on political unrest as a factor affecting state's participation in war for helping its alliance partner. Actually there have been long and increasing attentions to domestic unrest in causes-of-war literature. Proponents of diversionary war theory claim that unstable governments tend to initiate international conflict because domestically embattled leaders seek internal cohesion via external threat. Actually many historical cases such as the Falklands War and World War I tell us that political leaders who drove their states into war had faced domestic challenge to their leadership and striven for political survival. While critics of diversionary war theory point out lack of solid evidence for correlation between international conflict and domestic unrest (e.g. Meernik and Waterman 1996; Fravel 2010), international relations scholars have developed many hypotheses linking domestic unrest to international conflict in a sophisticated way and tested them in quantitative and qualitative ways. ${ }^{1}$ Surprisingly little attention has been paid to diversionary incentives as a factor affecting alliance politics. What impacts does political unrest have on alliance politics? What decisions do domestically vulnerable leaders make about their state's alliance partner?

This study argues that domestically-troubled states are reliable alliance partners, especially when the states are weaker than their allies. Joining military activities can make embattled leaders benefit from strong nationalism against foreign enemy, as well as from the stronger ally's military and economic aid. However, domestic unrest is not sufficient for high level of alliance commitment. Unpopular leaders can maintain their office and influence through various means. When they cannot take repression and reform due to lack of resources or institutional constraints, political leaders are more likely to answer their friends calling for help in order to divert public attentions from domestic ills and prove their capabilities to provide guns and butter.

In the rest of this paper, I firstly review alliance politics literature and develop a testable hypothesis about diversionary incentives and alliance commitment. Then, I carry out a preliminary test by tracing the process of South Korea's participation in the Vietnam War. Lastly, I summarize this study's finding and discuss its implications.

\section{THEORY: POLITICAL UNREST AND ALLIANCE COMMITMENT}

When do states (not) fight for their friends? Many realists agree that states write

\footnotetext{
${ }^{1}$ For critical reviews of diversionary war theory, see Levy (1989) and Oakes (2012, ch. 2).
} 
down alliance treaties in order to increase their military capabilities against common (potential) enemies. According to this balance-of-power approach, states that should deal with their threats but have resources not enough for military buildup tend to create alliances with other states that face the same threats (Waltz 1979; Walt 1987). Once states make alliance treaties, however, they often fear abandonment from their (stronger) alliance partners and/or fear entrapment into war initiated by or targeting (weaker) alliance partners (Snyder 1997). In alliance politics, states hate but also want to be free-riders. Accordingly, it is widely accepted that states are more likely to honor their alliance treaties when they expect more benefits of maintaining alliance relations and more costs of terminating them (Leeds 2003; Leeds and Savun 2007).

In addition to common threat, regime types have been paid increasing attentions by those who study alliance politics. Developing the thesis of democratic peace that there is no war between democracies, some scholars argue that democracies are reliable alliance partners due to their transparency of decision-making, stable civil-military relation, audience cost, and professional and depoliticized soldiers (Siverson and Emmons 1991; Lake 1992; Choi 2003; Lipson 2003; Pilster 2011). They provide some, if not strong, evidence about the positive relations between democracy and war victory (Reiter and Stam 2002), about democracy and alliance commitment (Choi 2004, 2012). Although some scholars dismiss the effects of democracy on alliance politics and war outcome (Desch 2002; Gartzke and Gleditsch 2004; Tago 2007), many people increasingly agree with the institutional approach that democracies not only do not fight each other but cooperate with each other well, often as reliable alliance partners.

What else should be considered to explain alliance commitment? This study shifts our focus to political unrest, defined here as serious domestic challenge to incumbent leadership. What policies do leaders choose when faced with domestic challenge to their leadership? While there have been relatively limited attentions to this question, we can find competing positions on this issue. Some argue that domestically vulnerable leaders tend to give more weight to alliance relations. Unpopular leaders have trouble in mobilizing domestic resources for military buildup, so they prefer relying on external forces for dealing with foreign threats (Barnett and Levy 1991). When leaders face a serious domestic challenge, they often prefer cooperation with other states, especially "secondary adversaries" and "neighboring states," in order to receive foreign help, political and military, and focus on the internal threat to their political survival (David 1991; Fravel 2005). According to Jung (2013), democratizing states under old-type leadership and/or having competition between civilian and military leadership show high alliance commitment because the leaders can slow down domestic 
reform but speed up civilian control of the military. It is reasonable to expect that domestically vulnerable leaders see joining a military conflict for alliance partner as a window of opportunity to distract public attention from domestic ills and to secure more resources from the alliance partner in return for their participation. In other words, unpopular leaders may seek rallying effects and demonstrate competence to domestic audience by helping their states' allies. ${ }^{2}$

This diversionary perspective on alliance politics should take into account at least two factors: (1) domestic backlash against joining a military coalition and (2) other policy options leaders can choose to deal with domestic unrest. First, domestically-challenged leaders may not choose foreign intervention because their decision can be criticized by domestic audience as unnecessary and risky. Especially in democracies where leaders cannot control idea market fully but are constrained by political opponents (Kaufmann 2004), leaders are reluctant to participate in other's war without bipartisan support. Second, leaders can save their political lives without diversionary use of force. By meeting the needs of winning coalitions in domestic politics or harshly repressing domestic opposition groups, they continue to play as a main political actor and seek to stabilize their political base without joining a foreign war. In short, domestic unrest is not sufficient for high commitment to alliance.

What affect embattled leaders' decision to help allies? Under what conditions are unpopular leaders likely to send troops for friends? I agree with the diversionary approach that political unrest creates political incentives for leaders to initiate international crisis. But it is not enough to make leaders choose joining war over other options such as domestic reform and repression. Only when leaders expect some benefits, military and economic, from their allies that they will help, they actively participate in war for their own political survival and domestic influence. Which type of allies can provide military and economic benefits in return for helping them during war? Stronger alliance partners provide some goods like security and aid, while weaker ones sacrifice their autonomy like territorial sovereignty and weapon development. Accordingly, it is reasonable that domestically challenged leaders seriously consider some gains like political support, open market, and military aid from stronger alliance partners before their decision to help the senior partners.

Hypothesis: Domestically-troubled states are more likely than other states to join wars for helping their stronger alliance partners.

\footnotetext{
${ }^{2}$ For the two mechanisms of diversionary conflict initiation - "rally around the flag" and "gambling for resurrection," see Haynes (2015).
} 
To check the validity of the above hypothesis, this study examines the historical case of South Korea's involvement in the Vietnam War. As detailed below, the United States called for its alliance partners' help in 1964 when it decided to intervene militarily in Southeast Asia. South Korea was one of the countries which positively responded to their senior partner's call, sending the second largest troops for South Vietnam next to the United States. By tracing the process of South Korea's decision to send troops to Vietnam, this "plausibility probe" case study aims to see whether this study's revised diversionary approach, linking political unrest and relative power within alliance to alliance commitment, has some explanatory power. ${ }^{3}$ As summarized in Table 1 , my diversionary approach and its competitors provide different expectations for the case of South Korea's alliance commitment to the United States in the Vietnam War. It was North Korea, not North Vietnam, that South Korea and the United States saw as their common threat. Moreover, South Korea was a much weaker partner not strong enough to help its big brother. In addition, South Korea had trouble in establishing a solid democracy in the post-Korean War period. It was not a liberal democratic partner to the United States, but a politically unstable country which just experienced the April Revolution (1960) and the May Coup (1961). Accordingly my diversionary approach expects South Korea's "high" alliance commitment to the United States, while the realist and institutional perspectives predict low (or medium) commitment. By tracing the process of South Korea's sending troop to South Vietnam, I can see whether the diversionary approach has some potential for explanatory power as a competitor to the realist and the institutional approach. 4

\footnotetext{
${ }^{3}$ For types of case study, see Levy (2008).

${ }^{4}$ I admit this single case study is not enough to make a conclusion about the explanatory power of diversionary approach. This is why I call this study one for "plausibility probe" rather than one for "hypothesis testing."
} 
Table 1. Three Approaches and South Korea's Sending Troops to Vietnam

\begin{tabular}{l|l|l|l}
\hline & $\begin{array}{l}\text { Main causal } \\
\text { variable }\end{array}$ & $\begin{array}{l}\text { South Korea and the U.S. in the } \\
\text { early/mid 1960s }\end{array}$ & $\begin{array}{l}\text { Expectation of South } \\
\text { Korea's alliance } \\
\text { commitment to } \\
\text { the U.S. during } \\
\text { the Vietnam War }\end{array}$ \\
\hline Realist approach & Common threat & $\begin{array}{l}\text { S Korea and the U.S. saw North } \\
\text { Korea as their main common enemy. }\end{array}$ & Low/Medium \\
\hline $\begin{array}{l}\text { Institutional } \\
\text { approach }\end{array}$ & Joint democracy & $\begin{array}{l}\text { S Korea experienced the 1961 } \\
\text { military coup led by General Park. }\end{array}$ & Low \\
\hline $\begin{array}{l}\text { Diversionary } \\
\text { approach }\end{array}$ & Domestic unrest & $\begin{array}{l}\text { S Korea had trouble in stabilizing } \\
\text { politics and boosting its economy in } \\
\text { the post-Korean War period. }\end{array}$ & High \\
\hline
\end{tabular}

\section{PROCESS-TRACING: SOUTH KOREA'S PARTICIPATION IN THE VIETNAM WAR ${ }^{5}$}

\section{OVERVIEW}

Why did Park Chung Hee send military troops to Vietnam? What made a small and poor state send a large number of soldiers abroad? South Korea joined the Vietnam War by sending non-combatants in 1964 and combatants during the following three years (see Table 2). Among 47,872 military personnel deployed in Southeast Asia, 3,094 were killed and 6,051 wounded as of February 1970 (US Congress 1970). Surprisingly, South Korea sent a much larger number of troops to Vietnam than did any other U.S. ally that answered the U.S. call for "more flags." As shown in Table 3, South Korean troops comprised 70 percent or more of U.S. allies' forces in Vietnam from 1965 to 1970. Some 50,00o South Korean soldiers fought with 550,000 US troops during the Vietnam War. It is puzzling that South Korea, which had suffered from economic underdevelopment and North Korea's military threat, dispatched a large number of soldiers abroad in order to help another state, South Vietnam. Although the South Korean government often justified its decision to its citizens as one which would repay debts they owed to the Free World members that participated in the Korean War, there were few who believed that this was a major motive of the large-scale military intervention.

\footnotetext{
${ }^{5}$ This section is adapted from the Chapter Five of the author's dissertation (Jung 2012).
} 
Table 2. South Korean Troop Dispatch to Vietnam

\begin{tabular}{l|l|r|l}
\hline Date & Type & \multicolumn{1}{|l|}{ Size } & Description \\
\hline Sep. 1964 & Non-Combatant & 140 & $\begin{array}{l}\text { Mobile Army Surgical Hospital \& Martial Arts } \\
\text { Instructors }\end{array}$ \\
\hline Mar. 1965 & Non-Combatant & 2,000 & Medics and Military Engineers \\
\hline Oct. 3, Oct. 16, 1965 & Combatant & 18,904 & Tiger Division w. Special Forces \& Marine Brigades \\
\hline Sep. 25-30, 1966 & Combatant & 23,865 & White Horse Division w. Special Forces \\
\hline Aug. 1967 & Combatant & 2,963 & Marine Brigades \& Special Forces \\
\hline
\end{tabular}

Source: US Congress (1970, 1570), Park (2007a, 295, Table 1) and Lee M. (2011, 409-410)

Table 3. Strength of US Allies' Military Assistance Forces, 1964-1970

\begin{tabular}{l|r|r|r|r|r|r|r}
\hline Year & 1964 & 1965 & 1966 & 1967 & 1968 & 1969 & 1970 \\
\hline \multirow{2}{*}{ Australia } & 200 & 1557 & 4525 & 6818 & 7661 & 7672 & 6763 \\
& $(42.8)$ & $(6.9)$ & $(8.6)$ & $(11.5)$ & $(11.6)$ & $(11.1)$ & $(10.0)$ \\
\hline \multirow{2}{*}{ Korea } & 200 & 20620 & 45566 & 47829 & 50003 & 48869 & 48537 \\
& $(42.8)$ & $(92.0)$ & $(86.6)$ & $(80.5)$ & $(76.0)$ & $(70.9)$ & $(72.0)$ \\
\hline \multirow{2}{*}{ Thailand } & 0 & 16 & 244 & 2205 & 6005 & 11568 & 11586 \\
& $(0.0)$ & $(0.1)$ & $(0.5)$ & $(3.7)$ & $(9.1)$ & $(16.8)$ & $(17.2)$ \\
\hline \multirow{2}{*}{ New Zealand } & 30 & 119 & 155 & 534 & 516 & 552 & 441 \\
& $(6.4)$ & $(0.5)$ & $(0.3)$ & $(0.9)$ & $(0.8)$ & $(0.8)$ & $(0.7)$ \\
\hline \multirow{2}{*}{ The Philippines } & 17 & 72 & 2061 & 2020 & 1576 & 189 & 74 \\
& $(3.6)$ & $(0.3)$ & $(3.9)$ & $(3.4)$ & $(2.4)$ & $(0.3)$ & $(0.1)$ \\
\hline \multirow{2}{*}{ Republic of China } & 20 & 20 & 23 & 31 & 29 & 29 & 31 \\
& $(4.3)$ & $(0.1)$ & $(0.0)$ & $(0.1)$ & $(0.0)$ & $(0.0)$ & $(0.0)$ \\
\hline \multirow{2}{*}{ Spain } & 0 & 0 & 13 & 13 & 12 & 10 & 7 \\
\hline \multirow{2}{*}{ Total } & $(0.0)$ & $(0.0)$ & $(0.0)$ & $(0.0)$ & $(0.0)$ & $(0.0)$ & $(0.0)$ \\
\hline
\end{tabular}

Note: Percentages are in parentheses.

Source: Larsen and Collins (1975, 23, Table 1)

In order to explain the small state's large military foreign intervention, scholars at first focused on the unequal alliance relation between the United States and South Korea. They saw South Korea was forced to participate in the Vietnam War (e.g. Lyman 1968; Han 1978; 1980; Chomsky and Herman 1979). South Korea was a weak alliance partner that seemed to have no option but to meet its strong partner's demand. In fact, its economic and military dependency on the United States was serious. U.S. aid to South Korea, military and economic, was $\$ 12.6$ billion dollars from 1946 to 1976 (around \$600 per capita), and it comprised 73 percent of South Korea's annual imports and 12 percent of its gross national product in 1961 (Woo 1991, 45-46; Lee M. 2011, 407). In addition, the United States main- 
tained its two combat divisions (52,00o military personnel from 1960 to 1963 and 48,000 from 1965) in order to deter another North Korean attack, although China withdrew all its forces from North Korea in 1958 (Macdonald 1992, 68). But South Korea could not expect continued and unconditional massive support from the United States anymore. As illustrated in Figure 1, the United States continued to reduce its military and economic aid to Korea after the Korean War and demanded that its allies share its burden. In addition, the 1953 Mutual Defense Treaty between South Korea and the United States lacked a provision requiring an automatic U.S. military response to an attack on South Korea (Macdonald 1992, 80-82; Lee M. 2011, 405). In this situation, South Korea made efforts to maintain its alliance partner's commitment to the Korean Peninsula out of fear of abandonment from the major power partner. To the small state, to be entrapped into a war seemed to be acceptable for its security and development. ${ }^{6}$ This is why many described South Korea's dispatch of troops to Vietnam as an example of a small state's selling autonomy for security. In other words, according to this view, South Korea's fear of abandonment led to its large-scale military intervention (Han 1978, 901-902). ${ }^{7}$

Figure 1. US Aid to South Korea, 1950-1965

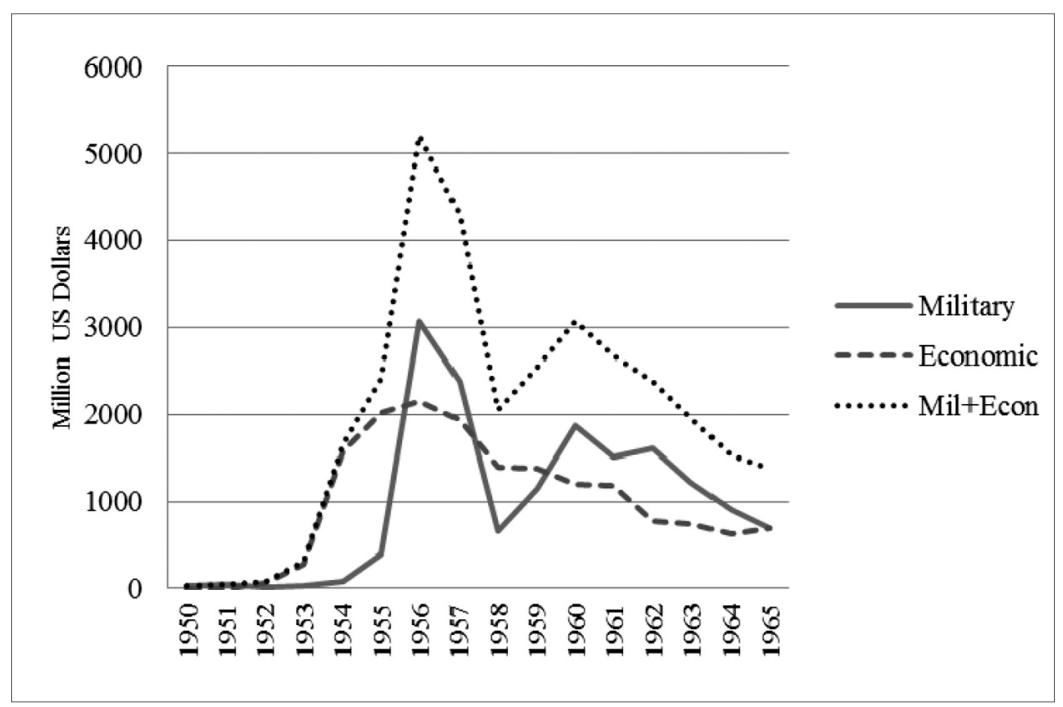

Source: U.S. Overseas Loan and Grants (http://gbk.eads.usaidallnet.gov/data/detailed.html)

\footnotetext{
${ }^{6}$ For the trade-off between autonomy and security in alliance policy, see Morrow (1991).

${ }^{7}$ For the dilemma between abandonment and entrapment in alliance politics, see Snyder (1997).
} 
But scholars began to oppose this view beginning in the 1990s. Mainly based on declassified U.S. and Korean governmental documents, they argued that it was South Korea's reasoned decision that produced the large-scale troop dispatch to Southeast Asia (e.g. Hong 1991; 1992; Choi 1996; Park 2005; 2006; 2007a; Lee M. 2011). They shed light on the fact that it was Park Chung Hee who first raised the issue of South Korea's military participation in Vietnam. In his state visit in November 1961, Park Chung Hee, who took power through the May 16 Coup, visited the United States and mentioned his intent to send South Korean troops abroad to U.S. President Kennedy:

With regard to Southeast Asia, particularly Viet-Nam, the Chairman [Park Chung Hee] stated that, as a firm anti-Communist nation, Korea would do its best to contribute to the security of the Fear East, North VietNam had well-trained guerrilla forces. Korea had a million men well trained in this type of warfare. These men had been trained in the regular forces and were now separated. With U.S. approval and support, Korea could send to Viet-Nam its own troops or could recruit volunteers if regular troops were not desired. Such action would prove that there was unity of action among the nations of the Free World. Just before he had discussed this question with his senior ROK officers. All were enthusiastic. He suggested that the president ask his military advisers to study this offer and let him know the results... (US Department of State 1998)

Although the United States did not accept this offer, Park Chung Hee and his aides did not abandon their plan to dispatch troops to Southeast Asia. In his report on President Johnson's press conference on June 15, 1964, U.S. Secretary of State Dean Rusk said that "[t]he Chairman of the Korean Joint Chiefs of Staff has asked our views on the possible use of Korean combat units in Vietnam.... We have told our Embassy that they should give no encouragement to the Koreans on this point but have requested that they push the idea of the Koreans contributing special forces advisors" (Cited from Hong 1991, 142).

Finally, South Korea sent its first combat division in 1965 when the United States decided to intervene militarily in Vietnam and asked its allies to contribute their combat troops. But only a small number of U.S. allies joined the Vietnam War, which was often regarded as a civil war. But South Korean leadership could pursue political and economic goals by participating in the war. According to the foreign minister's report to the president (January 6, 1961), five benefits of sending troops abroad were considered by the South Korean government:

1. Let the United States have a good feeling by satisfying its demands.

2. Link the issue of defending South Vietnam with our defense. If the 
United States gives up South Vietnam due to high costs, it can change its strategies toward Asia reducing its commitment to South Korea.

3. Domestically anti-communist ideas and slogans are weakening. Sending troops to South Vietnam can help make communists our concrete enemy. Also it will increase internal cohesion and strengthen anti-communist ideas.

4. Sending troops can increase the solidarity of anti-communist states in Asia... (IFANS 1965, 3).

For the reasons, South Korean leaders were neither reluctant to send their troops to Vietnam nor willing to do so at a low price. They were shrewd enough to draw much benefit from the U.S. During the period of 1965 to 1969 , South Korea is estimated to have earned $\$ 516$ million from various sources, including military commodity procurement, war risk insurance premiums, contracts for services, construction contracts, remittances of military and civilian personnel, and commercial exports (US Congress 1970, 1547). This is why one U.S. senator called South Korean soldiers in Vietnam "mercenaries" in the Hearing on the U.S. Security Agreements and Commitments Abroad (US Congress 1970). In short, many scholars now agree that South Korean leaders "were mainly motivated by Korean national interests, and therefore, the Korean participation was not necessarily or entirely at the behest of its superpower patron, the United States" (Hong 1991, 123).

However, one question remains as to why South Korea did not participate in the Vietnam War until 1965. As said above, Park Chung Hee tried to send combat troops from 1961 when he took political power through the Military Coup. Actually, General Park was not the first South Korean leader who considered a military intervention in Vietnam. In 1954, President Syngman Rhee made an offer to the United States to send a division in return for support for the establishment of five new Korean combat divisions (Macdonald 1992, 108-110; Lee M. 2011, 408). South Korean leaders whose leadership was shaken by domestic dissatisfaction had continued to dispatch troops to South Vietnam since the end of the Korean War but failed to do it until 1965. How can we explain the timing of the small state's foreign military intervention? Although there is a growing consensus about the claim that South Korea was an active rather than reluctant participant in the Vietnam War, scholars have not discussed fully the interaction between domestic and foreign conditions, which explain the timing of South Korea's sending troops to Southeast Asia.

\section{POLITICAL UNREST}

During the early 1960s, South Korea was struggling with severe political and eco- 
nomic unrest. After the March 15 presidential election in 1960, college and high school students began to protest against fraudulent elections and political corruption. President Syngman Rhee and his aides responded with brutal repression but failed to maintain their offices. After discovering the body of a high school student protestor who was allegedly killed in a demonstration and thrown into a bay by police, some 20,000 students and citizens marched to the presidential mansion, Kyoungmoodae, calling for President Syngman Rhee's resignation. Finally, the South Korean public succeeded in ousting the first South Korean president on April 26, 1960. But the April Revolution was not the end of the domestic unrest. Although the interim government drafted a new constitution establishing a parliamentary system and held a parliamentary election in July, the new Chang Myon government lacked the political leadership to initiate political and economic reforms that might have stabilized the state in the post-revolution period due to factional splits within the ruling Democratic Party (Macdonald 1992, 199208; Kim 2004, 41-48). Moreover, South Korea's economy was deteriorating during the period of the Second Republic. From December 1960 to April 1961, the price of rice increased by 60 percent and coal and oil prices by 23 percent; from November to February, national production fell more than 12 percent. The rate of unemployment was high: 23.4 percent in 1959 and 23.7 percent in 1960 (Kim 2004, 45-46).

Against this background, Major General Park Chung Hee came to power through the May 16 Military Coup in 1961. In justifying their military intervention into domestic politics as one "to give direction to our nation, which has gone dangerously astray," Park and his military officers announced a six-point political platform:

1. Oppose communism and reorganize and strengthen anti-communist readiness, which has been so far been asserted only rhetorically.

2. Respect the United Nations Charter, faithfully carry out international obligations, and strengthen ties with the United States and other freeworld allies.

3. Root out corruption and the accumulated evils in this nation and its society, instill moral principles and national spirit among the people, and encourage a new and fresh outlook.

4. Speedily solve the misery of the masses, which are reduced to despair, and concentrate on the construction of an independent national economy.

5. Increase the national capacity to achieve national unification, the unanimous goal of all Korean people, and to oppose communism.

6. Transfer power to new [generations of] conscientious politicians as soon as our mission has been completed, and return to our original [military] duties (Han 2011, 51). 
In short, the junta promised two things: providing security and boosting the economy. However, it lacked the resources to fulfill these promises. Park Chung Hee tried to maintain his country's lifeline, i.e. U.S. military and economic aid. Considering its underdeveloped economy and threated security, South Korea relied massively on its major power ally (see Table 4). When he ascended to power, Park Chung Hee made strong efforts to gain U.S. support expressing his willingness to oppose communism and his intention to improve relations between South Korea and Japan. Although he was invited to visit the U.S. as Chairman of the Supreme Council for National Reconstruction, he could not expect that U.S. aid would last in the future. As mentioned above, the United States was reducing its military and economic aid to South Korea after the Korean War and demanded that its East Asian allies, South Korea and Japan, contribute more to collective defense against communism. Actually, the United States tried to withdraw all troops from Korea and often demanded the reduction of South Korean forces in order to decrease its military aid.

Table 4. South Korea's GDP and US Economic Aid to Korea

\begin{tabular}{c|c|c|c}
\hline \multicolumn{2}{|c}{ South Korea's GDP } & US Economic Aid to Korea & \% \\
\hline & $(\mathbf{A})^{*}$ & $(B / A)$ & 56 \\
\hline 1961 & 2100 & 1173.371 & 33 \\
\hline 1962 & 2300 & 765.491 & 27 \\
\hline 1964 & 2700 & 735.8549 & 21 \\
\hline 1965 & 2900 & 622.0203 & 23 \\
\hline
\end{tabular}

*Bank of Korea (http://ecos.bok.or.kr/), ${ }^{* *}$ U.S. Overseas Loan and Grants, Unit: Million US dollars Source: http://gbk.eads.usaidallnet.gov/data/detailed.html

Park wanted to use national capital for economic development in his first years but failed. After announcing the first economic development five-year plan in January 1962, the junta initiated a series of economic policies such as increasing deposit interest rates and revitalizing the stock market and carried out currency reform, changing the currency denomination from hwan to won in order to secure domestic funds for economic development. But all these efforts failed to find "idle money" and caused more inflation and less development (Woo 1991, 8183; Kim 2004, 78-82; Park 2007b, 314-328). ${ }^{8}$ In addition, severe drought and flood led to the 1963 food crisis, which not only stopped South Korea's export of

\footnotetext{
${ }^{8}$ A decrease in economic growth was from 3.5 percent in 1961 to 2.8 percent in 1962.
} 
rice but forced the Korean government to call for more U.S. food aid (Macdonald 1992, 298-300). Accordingly, the junta announced the revised five-year plan in February 1964 after close consultation with the United States. The new plan was more oriented toward export-led development and introduction of foreign capital than the previous plan had been (Park 2007b, 329-344).

After retiring from the military, Park Chung Hee ran for and won the presidential election with a small margin of 151,595 votes, or 1.5 percent, in October 1963. Although he succeeded in maintaining his position as head of state, his leadership was facing serious challenges from both civilians and soldiers. As the U.S. wanted, Park, unlike the former South Korean leaders, aimed to quickly normalize diplomatic relations with Japan for economic reasons. There were five meetings for normalization between the governments of South Korea and Japan from 1951 to 1960 thanks to heavy pressure from the U.S. on its two East Asian allies. But public opposition and the political leaders' lack of willingness, especially in Korea, prevented progress until November 1961 when Director of Korean Central Intelligence Agency Kim Jong Phil met Japanese Foreign Minister Ohira Masyoshi. In his secret meeting with Ohira, Kim agreed to normalize diplomatic relations in return for reparations for Japan's wrongdoings during the colonial period, \$300 million in grants, $\$ 200$ million in government loans, and $\$ 100$ million dollars in commercial credits. When the memorandum was revealed by the Japanese Foreign Ministry in January 1962, Park Chung Hee faced fierce nationwide nationalistic opposition against "humiliating and unequal diplomacy" and "one-man diplomacy." He recalled Kim from Tokyo. But the Korean government resumed its normalization talks in 1965 when the United States promised its continued commitment to Korea after the normalization between its two East Asian allies, that is, it would not sell Korea to Japan. Although the South Korean public showed strong opposition to normalization with Japan through nation-wide antigovernment demonstrations (the June 3 Incident), President Park repressed them by proclaiming martial law and mobilizing four infantry divisions (Kim 2004, 96-101; Kim J. 2011, 172; Lee J. 2011, 439-452). In short, Park failed to secure public support for his leadership in 1965.

In addition, Park Chung Hee did not control the military completely. There were rifts within the military. In a telegram to the Secretary of Defense on September 21, 1964, the U.S. Joint Chiefs of Staff discussed a probable military coup in South Korea:

1. In view of the possibility of a coup in the Republic of Korea (ROK) and its impact on the operational control of the Korean Armed Forces exercised by the United States through the Commander in Chief, United 
Nations Command (CINCUNC), the Joint Chiefs of Staff have given consideration to appropriate courses of action available to CINCUNC.... 2. After considering the factors affecting the stability of the ROK Government and the nature of US involvement discussed in Appendix B hereto, the Joint Chiefs of Staff have concluded that:

a. An attempted coup in the ROK is possible. The most likely source of successful action to unseat the present regime is the military.

b. A successful procommunist coup is unlikely due to the presence of strong United Nations and South Korean Armed Forces, effective internal security, and the anticommunist orientation of the people (US Department of State 1999).

Actually, the junta was divided between progressive young members, on the one hand, and moderate senior members, on the other hand. When the government's Democratic Republican Party was established in January 1963, the two sides began a serious power struggle. Although Park Chung Hee sided with young members by eliminating General Chang Do Young and his supporters just after the success of the coup in 1961, he could not resist the moderate group's and U.S. pressure for removing Kim Jong Phil, a leader of the progressive group in 1963, who allegedly raised illegal political funds (Macdonald 1992, 217-219; Kim 2004, 84-85; Park 2007b, 259-263). In May 1965, more than twenty (former) military officers, including former junta member Won Chung-Yeon, were arrested for plotting a military coup. This shows that Park Chung Hee had some trouble in maintaining the loyalty of soldiers (Kim J. 2011, 180-185).

In sum, South Korea had suffered from domestic unrest causing vulnerable leadership since the April Revolution of 1960. Although he became a civilian president after succeeding in his military coup, Park Chung Hee failed to draw strong support from the public and from soldiers. In order to secure legitimacy of his rule, he focused on economic development but had trouble in finding capital, national and foreign, due to poor domestic savings and reduced foreign aid. Thus Park rushed to diplomatic normalization with Japan for more economic aids and trade benefits. But this diplomatic policy weakened the domestic position of Park Chung Hee and generated public opposition and the military's suspicion.

\section{UNITED STATES' CALL FOR "MORE FLAGS"}

It was in 1964 that South Vietnam was no longer able to defend itself from North Vietnam (for the rise of North Vietnam, see Figure 2). In his memorandum to President Lyndon Johnson on December 21, 1963, U.S. Secretary of Defense Robert McNamara expected that "unless current trends are reversed in the next few months, the result would be a neutral or communist Vietnam" (Cited from 
Hong 1992, 125-126). The U.S. concern about the expansion of communism in Asia led to its decision for military intervention and its call for "more flags" in South Vietnam. Answering the U.S. call, South Korea began to send non-combat forces in 1964 and combat forces in 1965. Although North Vietnam could not be a direct threat to South Korea, South Korea worried about the "domino effect" of the future unification of Vietnam under communism to other Free World states. The fall of South Vietnam could lead naturally to "explicit and radical aggressions by communists against free states in all the Pacific Rgion, including the Korean peninsula" (Park 1965a). Although China withdrew its troops from North Korea in 1958, its development of nuclear weapons triggered security concerns in its neighbors, including South Korea. In an address at the national rally against China's nuclear test in March 1965, President Park said not only that China's development of nuclear weapons aimed to "check the Free Bloc, expand its influence, and make more effective its detestable aggression scheme to communize all the world," but also that China "recently began to exert its evil influence in Southeast Asia in an explicit way" (Park 1965b).

On the other hand, the U.S. decision for military intervention in Vietnam increased South Korea's concern about the reduction of U.S. forces on the Korean Peninsula. As discussed above, South Korea continued its efforts to maintain or increase the level of U.S. and Korean troops in South Korea and called for U.S. support for the modernization of the Korean Army. Accordingly, South Koreans worried that the U.S. would move one or two divisions from the Korean Peninsula to Southeast Asia in order to reduce its war costs. Considering North Korea's military buildup and its resulting military gap (see Figure 3), it was reasonable for South Korea to make efforts to prevent the reduction of U.S. forces on the Korean peninsula and to maintain its major power alliance partner's commitment (Park 2000). In the 1967 presidential campaign, President Park insisted that his decision to send Korean troops abroad resulted from his strategic concerns about the relocation of U.S. troops from Korea to Vietnam (Han 2003, 132). In short, North Vietnam could not attack South Korea. But the communists' growing power increased the capitalist state's security concerns during the Cold War period. 


\section{Figure 2. Rise of North Vietnam}
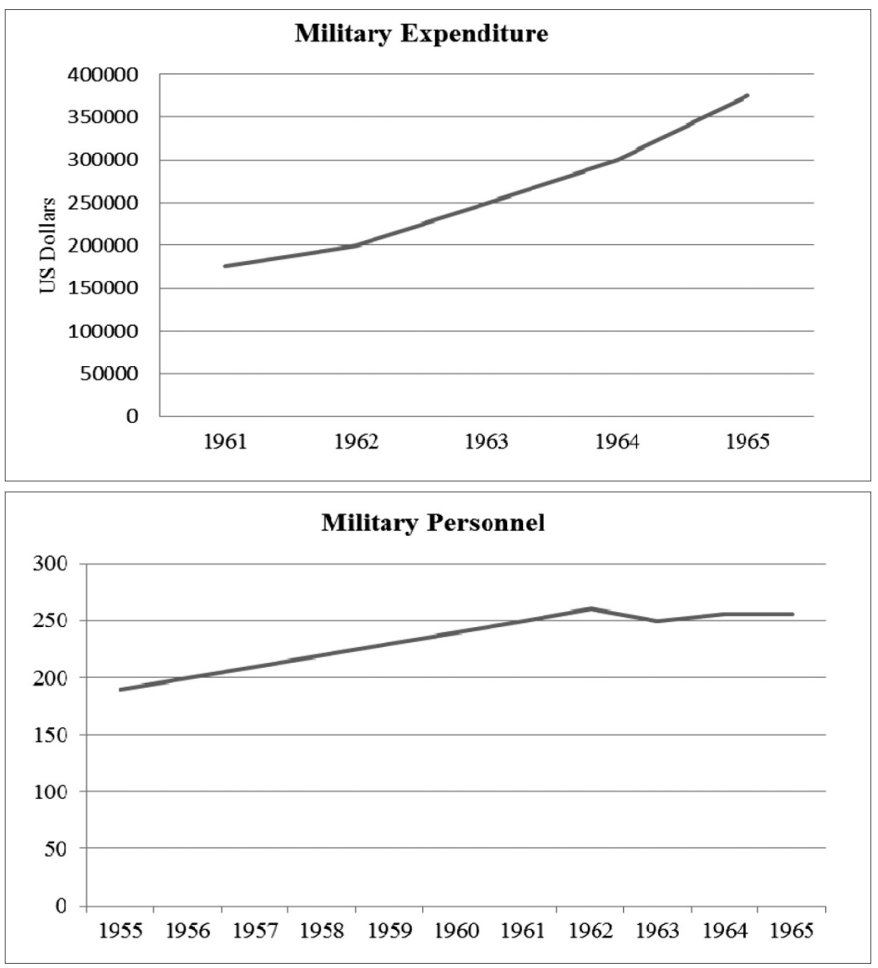

Source: Correlates of War Project (http://www.correlatesofwar.org/)

Figure 3. Two Koreas' Military Expenditure, 1960-1965

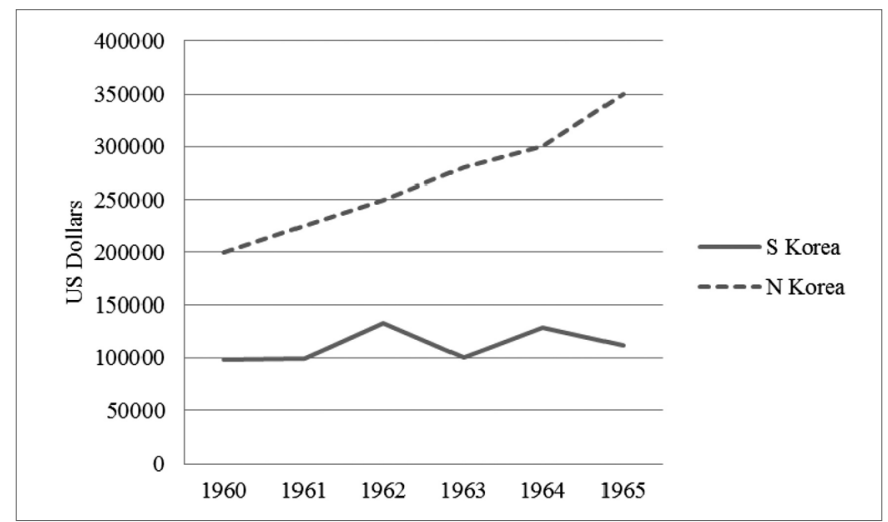

Source: Correlates of War Project (http://www.correlatesofwar.org/) 
It is very hard to find hard evidence of whether or not President Park decided to send combat troops to Vietnam in order to consolidate his control of domestic politics. Based on declassified U.S. and Korean documents, interviews, and memoirs, however, many scholars regard President Park's domestic political interests as one of the main factors leading to his troop dispatch decision (e.g. Hong 1991; Park 2007a, 292-294; Hong 2009, 223-226; Lee M. 2011, 404-408). While there is no consensus on whether we should interpret his Vietnam policy as one seeking regime interest, national interests, or both, few dismiss the notion that (potential) domestic challenges to the South Korean leadership contributed to its foreign military intervention. Some argue that South Korea's participation in the Vietnam War paved the way for a "garrison state" or President Park's long dictatorship in South Korea (Han 2003). In fact, President Park is often described as seeking support from two (potential) challengers, soldiers and the public, to his leadership during the Vietnam War:

\begin{abstract}
It was possible for Park to expect that factionalism in the military would significantly be reduced once they were sent to Vietnam. The war provided the military a rare opportunity to satisfy its corporate interest. Most high ranking officers were handpicked by Park Chung Hee, and their junior officers were again selected by themselves. Personal loyalties to Park Chung Hee were naturally built along command lines. The members participating [in] the war had various advantages in promotion and welfare. A series of potential counter coups, that challenged him during the initial period of the military junta, seemed to have disappeared throughout the remaining years of his presidency...

....as for the grass-roots mobilization, the ROK government wrote a series of national songs for sending units to Vietnam. In every classroom, school children were instructed about the rationale of ROK's participation and were asked to write letters and to send gifts for encouraging the soldiers in Vietnam. In every home TV broadcast these national songs before regular programs. As a result, the mood was rife for people to believe that Koreans could finally do something good for international crusade for freedom (Hong 1991, 117-118, 148).
\end{abstract}

By providing some opportunities and benefits to the military, he drew support from the military, especially from the young rising officers. In addition, he sold his policy of foreign military intervention to the public as one increasing national prestige as well as providing national security. It cannot be explained why South Korea sent many more troops to Vietnam than did other U.S. allies without considering the South Korean leader's diversionary incentives. So it is reasonable to conclude that President Park's vulnerable leadership made him willing to initiate a militarized conflict and the decline of South Vietnam provided 
him with an opportunity to do it.

\section{SUMMARY AND DISCUSSION}

Overall, this case study's findings corroborate my revised diversionary approach to alliance politics. During the early 1960s, South Korea suffered from political and economic unrest. Its leadership changed twice in two years in the wake of the April Revolution of 1960 and the May Coup of 1961. After restoring a civil government, President Park Chung Hee, a former military coup leader, initiated economic reforms and but failed to find domestic capital and reboot the economy. Its diplomatic policy to normalize relations with Japan ignited an anti-government mood leading to nation-wide demonstrations. In addition, Park was concerned about a counter-coup by dissatisfied military officers. When the United States decided to intervene militarily in Southeast Asia and called its allies for combined forces, Park was eager to respond to the call by sending noncombat and combat troops to Vietnam. It is widely accepted that President Park's expectation of rally effects was one of the driving forces leading to the small state's large scale, multi-year intervention in foreign territory. Still, there were other contributing factors producing South Korea's military participation such as South Korea's expectation of economic gains and military assistance from the U.S.

This qualitative study tells us when and how domestic unrest affects alliance politics. Park Chung Hee tried to send military troops just after he gained power in 1961. This shows that the unpopular leader's diversionary incentive was a main factor for his decision to participate in the Vietnam War in 1964. But we should ask why Park wanted the Vietnam War. By showing his anti-communist stance and commitment to alliance with the Unite States, he hoped to maintain, if not increase, U.S. support, military and economic, that was essential not only for South Korea's security and development but for his political survival and control of domestic politics. In other words, Park could prove himself to disgruntled domestic audience as one providing "guns" (security) and "butter" (economic development) with U.S. support in return for his sending troops to Southeast Asia. In short, South Korea seemed to be entrapped to its stronger partner's war, but its leader did not avoid the trap.

\section{REFERENCES}

Barnett, Michael N. and Jack S. Levy. 1991. "Domestic Sources of Alliance and 
Alignments: The Case of Egypt, 1962-73." International Organization 45(3), 369-395.

Choi, Ajin. 2003. “The Power of Democratic Cooperation." International Security 28(1), 142-153.

. 2004. "Democratic Synergy and Victory in War, 1816-1992." International Studies Quarterly 48(3), 663-682.

. 2012. "Fighting to the Finish: Democracy and Commitment in Coalition War." Security Studies 21(4), 624-653.

Choi, Dong-Ju. 1996. "The Background to Korea's Involvement in the Second Indochina War." Korean Political Science Review [in Korean] 30(2), 267287.

Chomsky, Noam and Edward S. Herman. 1979. The Washington Connection and Third World Fascism(1st edition). Boston: South End Press.

David, Steven R. 1991. "Explaining Third World Alignment.” World Politics 43(2), 233-256.

Desch, Michael C. 2002. "Democracy and Victory: Why Regime Type Hardly Matters." International Security 27(2), 5-47.

Fravel, M. Taylor. 2005. "Regime Insecurity and International Cooperation: Explaining China's Compromises in Territorial Disputes." International Security 30(2), 46-83.

. 2010. "The Limits of Diversion: Rethinking Internal and External Conflict.” Security Studies 19(2), 307-341.

Gartzke, Erik and Kristian Skrede Gleditsch. 2004. "Why Democracies May Actually Be Less Reliable Allies." American Journal of Political Science 48(4), 775-795.

Han, Sungjoo. 1978. "South Korea's Participation in the Vietnam Conflict: An Analysis of the Us-Korean Alliance." Orbis 21(4),893-912.

. 1980. "South Korea and the United States: The Alliance Survives." Asian Survey 20(11), 1075-1085.

Han, Hong-Gu. 2003. "The Park Chung Hee Administration's Troop Dispatch to Vietnam and the Road to Garrison State." Critical Review of History [in Korean] 62, 120-139.

Han, Yong-Sup. 2011. "The May Sixteenth Military Coup.” In Byung-Kook Kim and Ezra F. Vogel eds., The Park Chung Hee Era: The Transformation of South Korea, Cambridge: Harvard University Press, 35-57.

Haynes, Kyle. 2015. "Diversionary Conflict: Demonizing Enemies or Demonstrating Competence?" Conflict Management and Peace Science, doi: 0738894215593723.

Hong, Kyudok. 1991. "Unequal Partners: ROK-US Relations During the Vietnam 
War.” Ph.D Dissertation, University of South Carolina. . 1992. "All the Way with the Americans: Reflections on the ROK's Foreign Policy during the 1960s." Korean Journal of International Relations [in Korean] 32(2), 23-44.

Hong, Seuk-ryule. 2009. "Dangerous Honeymoon: Rok-Us Relations During Johnson Administration, and the Vietnam War." Critical Review of History [in Korean] 88, 216-383.

Institute for Foreign Affairs and National Security(IFANS). 1965. "Concerns about Sending Troops to South Vietnam." South Korea's Military Assistance to South Vietnam [in Korean] 15, Historical Records on the Vietnam War, Yonsei University Institute of State Governance Studies.

Jung, Sung Chul. 2012. "Fear and Greed: Domestic Unrest, Foreign Target, and Interstate Conflict." Ph.D Dissertation, Rutgers University-New Brunswick.

. 2013. "Democratization and Alliance Commitment: US Democratizing Allies during the Gulf War." Armed Forces \& Society 39(4), 654-674.

Kaufmann, Chaim. 2004. "Threat Inflation and the Failure of the Marketplace of Ideas: The Selling of the Iraq War." International Security 29(1), 5-48.

Kim, Hyung-A. 2004. Korea's Development under Park Chung Hee: Rapid Industrialization, 1961-79. London: Routledge Curzon.

Kim, Joo-Hong. 2011. "The Armed Forces." In Byung-Kook Kim and Ezra F. Vogel eds., The Park Chung Hee Era: The Transformation of South Korea, Cambridge: Harvard University Press, 168-199.

Lake, David A. 1992. "Powerful Pacifists: Democratic States and War." American Political Science Review 86(1), 24-37.

Larsen, Stanley R. and James Lawton Collins. 1975. Allied Participation in Vietnam, Vietnam Studies. Washington: U.S. Government Printing Office.

Lee, Jung-Hoon. 2011. "Normalization of Relations with Japan: Toward a New Partnership.” In Byung-Kook Kim and Ezra F. Vogel eds., The Park Chung Hee Era: The Transformation of South Korea, Cambridge: Harvard University Press, 430-456.

Lee, Min Yong. 2011. “The Vietnam War: South Korea's Search for National Security." In Byung-Kook Kim and Ezra F. Vogel eds., The Park Chung Hee Era: The Transformation of South Korea, Cambridge: Harvard University Press, 403-429.

Leeds, Brett Ashley, Andrew G. Long, and Sara McLaughlin Mitchell. 2000. "Reevaluating Alliance Reliability: Specific Threats, Specific Promises." Journal of Conflict Resolution 44(5), 686-699. 
Leeds, Brett Ashley. 2003. "Alliance Reliability in Times of War: Explaining State Decisions to Violate Treaties." International Organization 57(4), 801-827. Leeds, Brett Ashley and Burcu Savun. 2007. "Terminating Alliances: Why Do States Abrogate Agreements?” Journal of Politics 69(4), 1118-1132.

Levy, Jack S. 1989. “The Diversionary Theory of War: A Critique.” In Manus I Midlarsky ed., Handbook of War Studies, Boston: Unwin Hyman, 259288.

. 2008. "Case Studies: Types, Designs, and Logics of Inference." Conflict Management and Peace Science 25(1), 1-18.

Lipson, Charles. 2003. Reliable Partners: How Democracies Have Made a Separate Peace. Princeton: Princeton University Press.

Lyman, Princeton N. 1968. “Korea's Involvement in Viet Nam.” Orbis 16 (2), 563580 .

Macdonald, Donald Stone. 1992. U.S.-Korean Relations from Liberation to SelfReliance: The Twenty-Year Record. Boulder, CO: Westview Press.

Meernik, James D. and Peter Waterman. 1996. "The Myth of the Diversionary Use of Force by American Presidents.” Political Research Quarterly 49(3), 573-590.

Morrow, James D. 1991. "Alliances and Asymmetry: An Alternative to the Capability Aggregation Model of Alliances." American Journal of Political Science 35(4), 904-933.

Oakes, Amy. 2012. Diversionary War: Domestic Unrest and International Conflict. Stanford: Stanford University Press.

Park, Chung Hee. 1965a. "Presidential Statement on Sending Troops to South Vietnam.” Accessed at http://www.pa.go.kr/research/contents/speech/ index.jsp (Junuary 26, 2016).

. 1965b. "An Address at the Rally against PRC's Nuclear Test." March 10 Accessed at http://www.pa.go.kr/research/contents/speech/index.jsp (January 31, 2016).

Park, Tae-Gyun. 2000. "U.S. Military Policy toward South Korea and Responses of the Korean Government in 1950 and 1960s." Journal of International and Area Studies [in Korean] 9(3), 31-53.

. 2005. "Security Crises and the Second Economy in the Middle of 1960s." Critical Review of History [in Korean] 72, 250-276.

. 2006. "Negotiation Process of Korean Combat Troop Dispatch to Vietnam between Korea and the U.S." Critical Review of History [in Korean] 74, 144-189.

. 2007a. "Between Memory and Oblivion: The Dispatch of Korean Combat Troops to Vietnam." Critical Review of History [in Korean] 80, 
288-311.

. 2007b. Archetype and Metamorphosis: The Origins of Korea's Economic Development Plans [in Korean]. Seoul: Seoul National University Press.

Pilster, Ulrich. 2011. "Are Democracies the Better Allies? The Impact of Regime Type on Military Coalition Operations.” International Interactions 37(1), $55-85$.

Siverson, Randolph M. and Juliann Emmons. 1991. "Birds of a Feather: Democratic Political Systems and Alliance Choices in the Twentieth Century." Journal of Conflict Resolution 35(2), 285-306.

Snyder, Glenn H. 1997. Alliance Politics. Ithaca: Cornell University Press.

Tago, Atsushi. 2007. "Why Do States Join US-led Military Coalitions? The Compulsion of the Coalition's Missions and Legitimacy." International Relations of the Asia-Pacific 7(2), 179-202.

US Congress. 1970. "United States Security Agreements and Commitments Abroad: Republic of Korea." Subcommittee on US Security Agreements and Commitments Abroad, Committee on Foreign Relations, US Senate, Hearings, 91st Congress, 2nd Session. Washington DC: Government Printing Office.

US Department of State. 1998. "Document 247: Memorandum of Conversation." Foreign Relations of the United States 1961-1963, 12 (China, Korea, Japan).

. 1999. "Document 22: Memorandum from the Joint Chiefs of Staff to Secretary of Defense McNamara.” Foreign Relations of the United States 1964-1968, 19 (Korea).

Walt, Stephen M. 1987. The Origins of Alliances. Ithaca: Cornell University Press.

Waltz, Kenneth N. 1979. Theory of International Politics. Reading: AddisonWesley.

Woo, Jung-en. 1991. Race to the Swift: State and Finance in Korean Industrialization. New York: Columbia University Press. 